\title{
A new species of the "mateusi" group: Iberobathynella ortizi sp.n. (Crustacea, Syncarida, Parabathynellidae)
}

\author{
ANA ISABEL CAMACHO
}

Accepted 8 August 1988

\begin{abstract}
Camacho, A.I. 1989. A new species of the "mateusi"group: Iberobathynella ortizi sp.n. (Crustacea. Syncarida, Parabathynellidae).-Zool. Scr. 18: 405-410.

A new species of the genus Iberobathynella Schminke, 1973, is described. The specimens were found in Cova do Rei Cintolo, Lugo, Spain. The species is included in the 'mateusi" group. according to Schminke's (1973) cladistic analysis.

Ana Isabel Camacho, Museo Nacional de Ciencias Naturales, Jose Gutierrez Abascal 2, E-28006 Madrid, Spain.
\end{abstract}

\section{Introduction}

Since Schminke (1973) proposed the genus Iberobathynella for four species from Portugal and one from the Eastern Pyrenees in France, four additional species from the Iberian Peninsula, and one from Morocco (Boutin \& Coineau in press; Camacho pers. obs.; Camacho \& Coineau 1987), have been described.

In this article a new species of Iberobathynella found in a cave in Lugo, Spain, is described and its relationship to the other species in the genus are evaluated. Thus, to date, a total of 11 species are described from the Iberian Peninsula, Eastern Pyrenees and Morocco.

The finding of Iberobathynella ortizi sp.n. in one of the few calcareous areas of Galicia, northwest Spain, seems to be of considerable biogeographical interest.

\section{Material}

Eleven specimens ( 5 males, 4 females and 2 juveniles with 4 pairs of thoracopods) were collected by Prof. E. Ortiz in Cova do Rei Cintolo $\left(43^{\circ} 23^{\prime} 40^{\prime \prime} \mathrm{N} ; 7^{\circ} 22^{\prime} 00^{\prime \prime} \mathrm{W}\right.$; altitude $\left.375 \mathrm{~m}\right)$ in Monte Cotorredondo Mondonedo (Lugo) on 13 Aug. 1969. The description is based on the 9 adult specimens that constitute the type series. Six specimens ( 3 males and 3 females) were dissected. The type specimens are located at the Museo Nacional de Ciencias Naturales, Madrid, Spain.

\section{Iberobathynella ortizi sp.n. (Figs. 1-3)}

Type material. Holotype and 8 paratypes, from Cova do Rei Cintolo, Lugo, Spain.

\section{Description}

Body. Total length of males, $1.22-1.27 \mathrm{~mm}$, of females 1.19-1.25 mm. Body elongated, segments progressively lengthened and widened towards posterior end of body. Head longer than wide.
Antenna I (Fig. 1A). Generally with 7 short. thick segments, the first being thickest, the remainder becoming progressively thinner. Length of first 4 segments greater than that of last 3,5 th segment relatively short. No sexual dimorphism.

Setation:

segment 1,3 setae of type a and 3 plumose setae:

segment 2, 1 seta of type a and 4 plumose setae;

segment 3, 2 long, smooth setae and 1 short, smooth one:

endopodite, 3 smooth terminal setae;

segment 4, 2 long plumose setae. 1 short plumose seta and 2 small projections;

segment 5, 3 simple, smooth setae and 2 aesthetes; segment 6,4 simple setae and 3 long aesthetes;

segment 7,4 simple setae and 3 aesthetes, one long and 2 shorter ones.

Antenna II (Fig. 1B). Small, with 3 segments, last of which longest, with 2 smooth and 1 plumose terminal seta and a small, shorter seta in the middle.

Labrum (Fig. 1C). With 8 uniform, apical teeth and a sharp. smaller lateral tooth on either end.

Mandibles (Figs. 1D, E). Pars incisiva with 4 equally developed teeth and a smaller 5th. Proximal tooth of pars incisiva on ventral mandibular margin very large, with 2 setae on its base.

Pars molaris with 3 strong distal teeth with denticles and 3 proximal teeth without denticles but a large quantity of fine setae. Groups of setae inserted on base of teeth.

Mandibular palp exceeds pars incisiva with a long base.

First maxilla (Fig. 1F). With 2 endites, proximal endite with 4 spines of different sizes. Distal endite with 6 teeth: 2 smooth apical ones, distal one being longest, the other 4 with spines and setae, proximal one being smallest. 3 subterminal setae on outer border. 


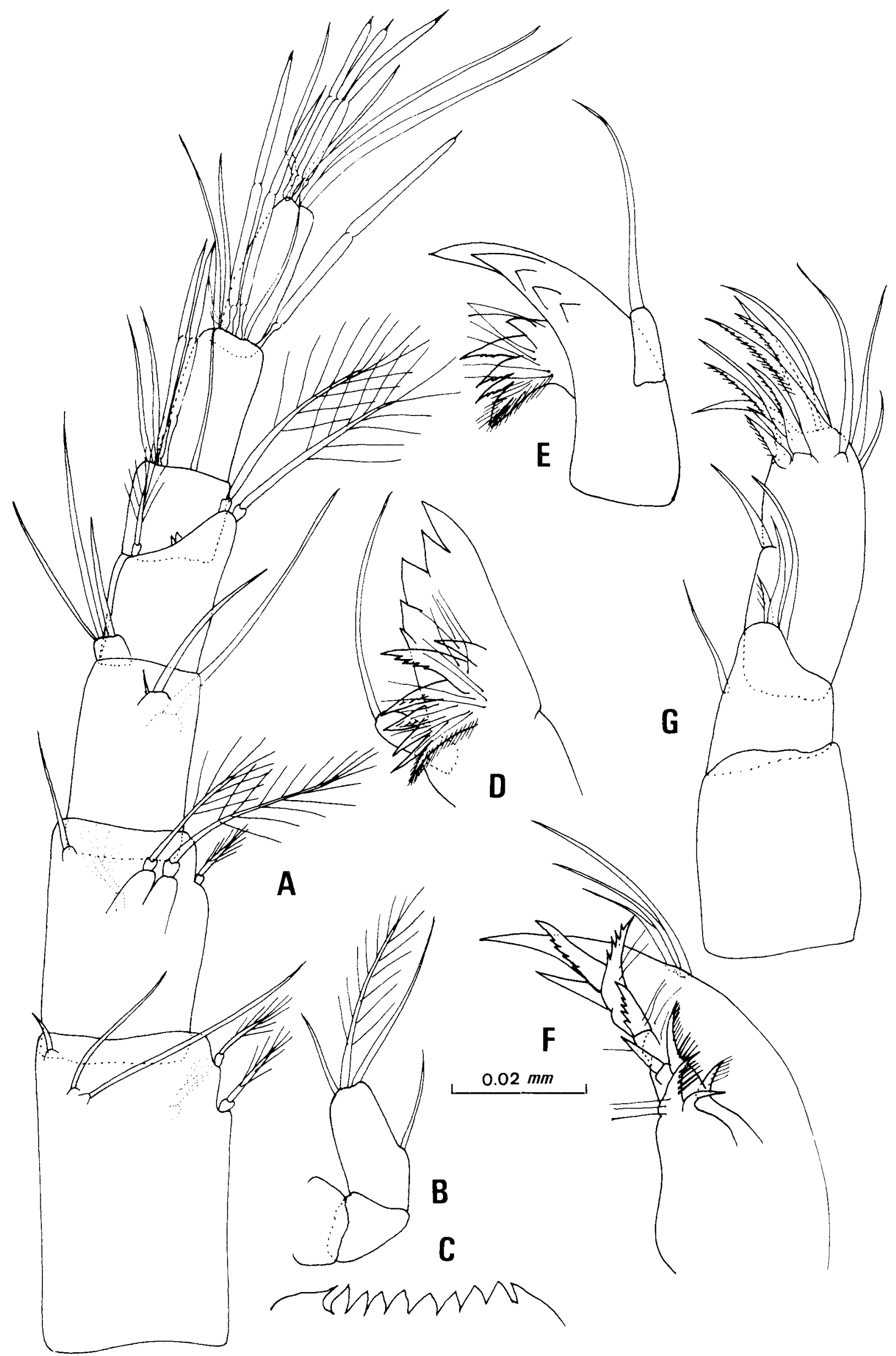

Fig. 1. Iberobathynella ortizi sp.n.-A. Antenna I (male). Dorsal view. $-B$. Antenna II (female). Dorsal view. C C. Labrum (female). Ventral view. $-D, E$. Mandibles. $-D$. Ventral view (male) - E. Lateral view (female). $-F$. Maxilla I (male). Lateral view.- $G$. Maxilla II (male). Lateral view. 
Second maxilla (Fig. 1G). 3-segmented, no setae on basal segment. 2nd segment apically with 2 well developed setae and a shorter one with microsetae, 1 additional seta on inner border. 3rd segment elongated, with 14 setae, 1 ventro-medial, 8 more or less smooth ones subterminally or terminally, 2 long, small ones, and 3 shorter ones with small setae.

Thoracopods 1-7 (Figs. 2A-C). 7 pairs of well developed thoracopods, in addition to the modified 8th pair. Length gradually increasing from pair 1 to 4 , last 3 pairs similar in size. Well developed epipodite on pairs $2-7$, exceeding half of the basipodite.

First segment of exopodite generally of same length as first two segments of endopodite.

Basipodite with 1 lateral, terminal seta.

Thoracopod 1 (Fig. 2A), Short. Exopodite monoarticulated, with 1 ventral seta with secondary setae and 2 terminal setae (1 plumose, the other barbed). Endopodite of 4 segments, 1st with smooth, distal seta, 2nd with 1 smooth and 1 plumose seta, 3 rd with 1 small, smooth and 1 tiny seta. Terminal segment with 2 claws and 1 seta. Latter segment with 2 groups of ctenidia on base of setae.

Thoracopods 2-7 (Figs. 2B, C). Exopodite biarticulated, 1st segment with 2 terminal barbed setae, 1 short and 1 long, 2nd segment with 2 terminal setae, 1 barbed, the other plumose. Ctenidia at base of setae.

Endopodite of 4 segments, 1st short and lacking setae, 2nd with 2 groups of lateral ctenidia, 1 plumose, smooth seta, 3 rd with 1 tiny seta and 2 groups of ctenidia, 4 th with 1 seta and 2 strong claws.

Thoracopod 8 male (Figs. 3A-C). Large and elongated, longer than wide when viewed laterally; basal region massive, relatively elongated (higher than wide); outer lobe $(a)$ with all sides regularly convex, giving it a very characteristic curved appearance, hardly longer than wide, clearly separated from basal region. Dentate lobe $(b)$ with 7 teeth. Basipodite (c) with subrectangular outline and 1 short seta at the end. Endopodite (d) elongated. protruding a little from the whole and displaying 2 setae of different size, 1 smooth and 1 barbed. Exopodite $(e)$ small and curved, with 2 small claws.

Thoracopod 8 female (Figs. 3C-E). Small, elongated, with 2 distinct teeth, 1 terminal, the other in middle region, elongated and with curved ends.

Dorsal margin of pleotelson (Figs. 3F, G). With pronounced, well developed anal operculum; outline of latter curved. Laterally 1 barbed seta.

Uropods (Fig. 3H). Sympod shorter than wide, a little longer than endopodite. With 5 thick, barbed spines, taking up practically whole length of sympod, last spine being very long and thick. Endopodite much longer than exopodite, in lancet form, with 2 barbed setae of different length in lateral position. Exopodite with 3 barbed setae, of which distal longest and thickest, and with 1 small, plumose seta basiventrally.

Furca (Fig. 3G). Curved and solid, with 7 spines, the 2 most distal with short. thick secondary setae. Rim of furca at base of terminal spine covered with row of setules. There are 2 dorsal setae, one large, plumose, the other shorter, barbed.

Enmology, Lesobahnella ortizi is dedicated to Prof. Eugenio Ortiz who kindly provided the material of Syncardia collected in Cova do Rei Cintolo in 1969

\section{Discussion}

Iberobathynella ortizi is very similar to $L$. cavadoensis (Noodt \& Galhano, 1969) and L. asturiensis Serban \& Comas i Navarro, 1978. It belongs to the group that Schminke (1973) calls "mateusi", which includes $I$. mateusi (Galhano, 1967). I. cavadoensis, and also $I$. asturiensis according to Serban \& Comas i Navarro (1978)

The description of the new species has revealed the existence of new characters and character states whose polarities are difficult to define in accordance with the methodology used by Schminke to obtain the cladogram for the genus Iberobathynella.

On the other hand. I have found species in Spain previously described from Portugal which show slight morphological differences from the original description. To complete the insufficient information in these original descriptions and to establish the range of populational variability, a redescription of some of these species ( $I$. cavadoensis and I. mateusi) is urgently needed.

Due to these two facts. my discussion will focus on traditional comparisons with the other species in terms of weighted similarity.

The new species shares the following features with the "mateusi" species group:

the presence of a pronounced anal operculum:

six teeth in the distal endite of the Mx.I;

no setae on the first segment of the Mx.II;

presence of 3 setae on the exopodite of the uropod (the type species $I$. cavadoensis has only 2 setae, whereas the Spanish specimens have 3):

one seta on segment 1 of the endopodite of Th.1:

Th. 1 exopodite monoarticulate.

Moreover the following characters are also shared by the new species and $I$. cavadoensis:

similar number and size proportions of the teeth on the sympod of the uropod;

endopodite of uropod longer than exopodite;

the general morphology of female Th. 8 .

The new species and $I$. asturiensis agree in the following characters:

endopodite of uropod with two differently sized barbed setae (in the original description of I. asturiensis they have the same length, but in the Spanish specimens they are different);

teeth of the mandibular pars incisiva of similar size:

the same number of serrated teeth on the distal segment of Mx.II.

The main difference from 1. mateusi is the presence of 7 pairs of developed thoracopods in the new species instead of 6 pairs. 


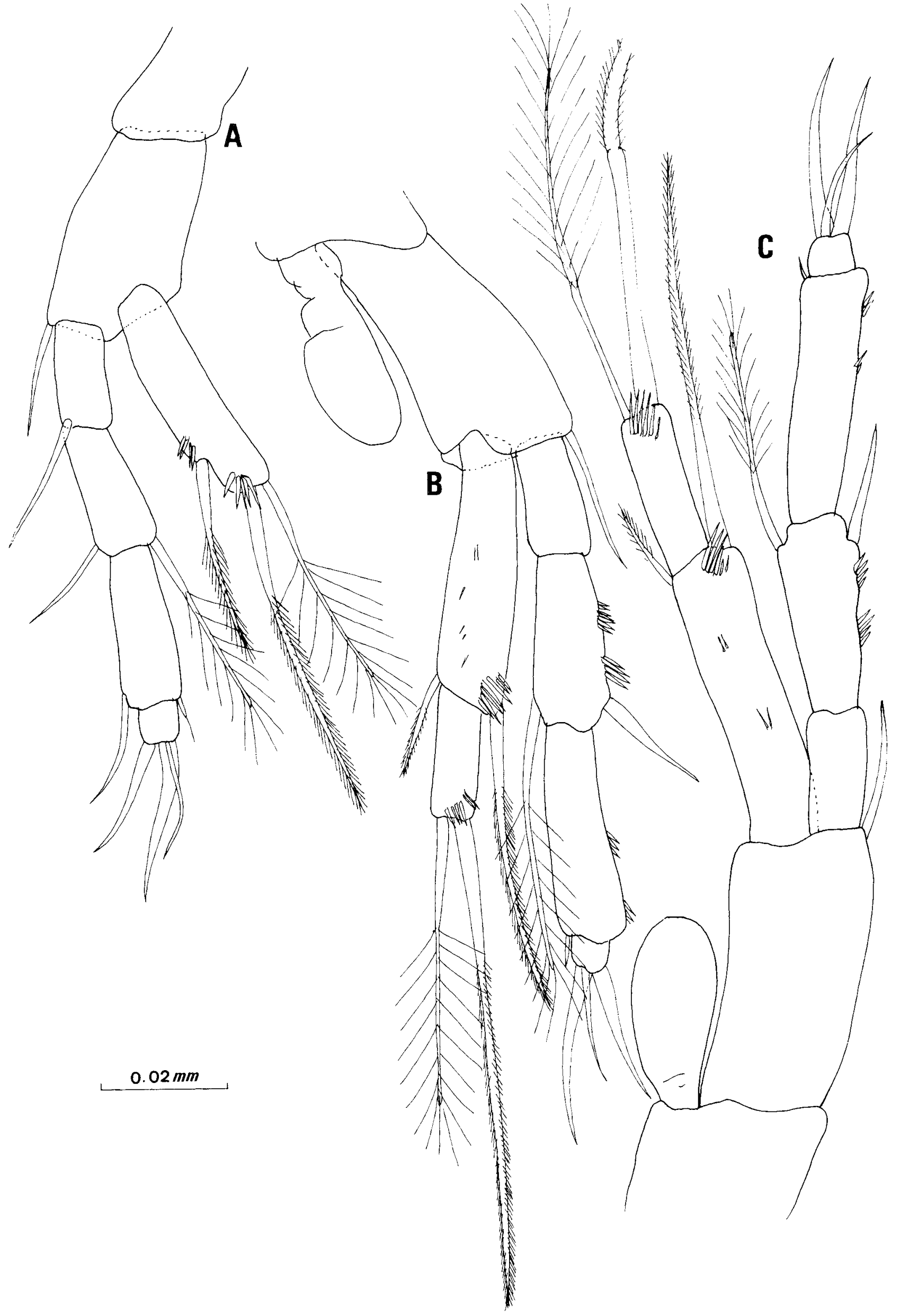

Fig. 2. Iberobathynella ortizi sp.n. Male-A. Thoracopod 1.-B. Thoracopod 3.-C. Thoracopod 7. 


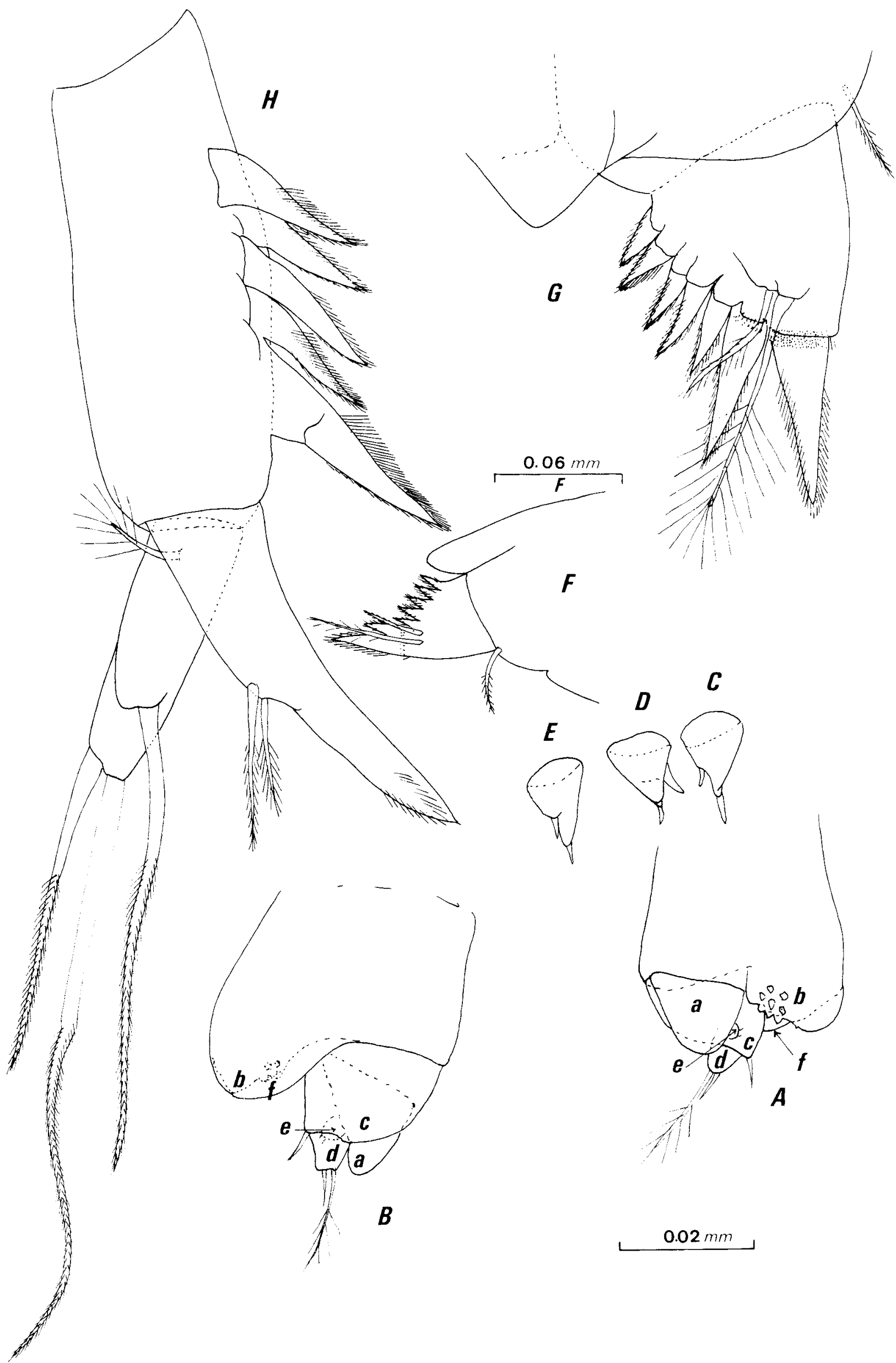

Fig. 3. Iberobathynella ortizi sp.n.-A, B. Thoracopod 8 (male).-A. Latero-external view.-B. Latero-internal view. $a$ outer lobe. $b$ dentate lobe, $c$ basipodite, $d$ endopodite, $e$ exopodite, $f$ inside lobe $-C, E$. Thoracopod 8 (female). Lateral view. $-F$. Pleotelson (male). Lateral view. $-G$. Furca (male). Dorsal view. $-H$. Uropod (male). Latero-internal view. 


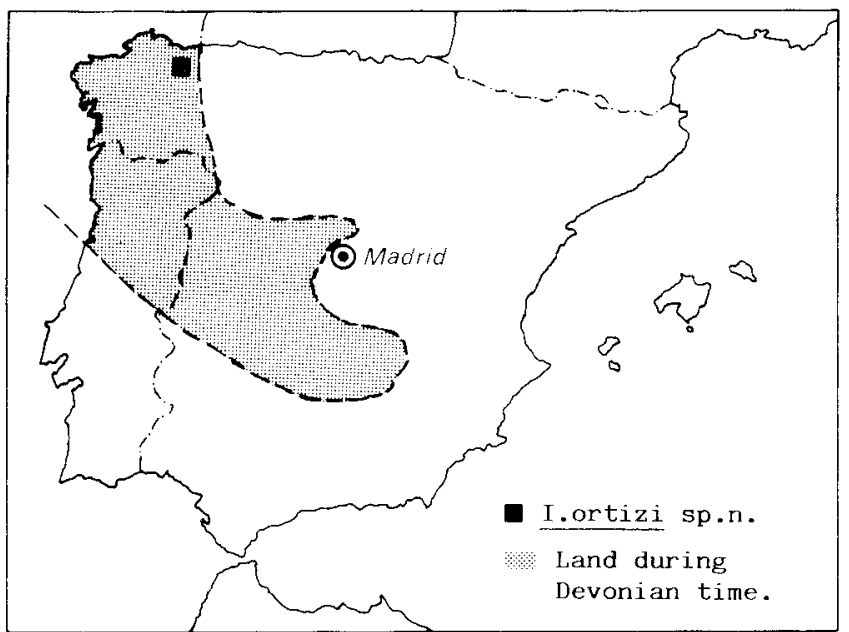

Fig. 4. Land during Devonian time and locality of lberobathyella ortizi sp.n. in Spain.

Diagnostic characters of $I$. ortizi are:

10 teeth in the labrum;

largest anal operculum in the species group;

sympod spines of uropod very thick and long;

P. 8 female small, triangular and with 2 rounded prolongations;

outer lobe of Th. 8 male round in general, but with concave sides, and a clear basal edge, edge of inner lobe serrated, basipodite and endopodite setae smooth.

\section{Biogeographical comments}

Cova do Rei Cintolo, the only locality where Iberobathynella ortizi sp.n. has been found. is located in one of the scarce calcareous outcrops of Galicia (northwest Spain). The cave has a horizontal length of over 6 $\mathrm{km}$, is of Cambrian (low and middle) material and opens onto the south side of the Abrea-Valinadares river valley (Puch 1987).

From a geographical point of view it is interesting to note that these old calcareous areas have not been affected by major marine transgressions since the Paleozoic. This species is thus found in an area that has emerged since the
Devonian, when water covered almost all of the Iberian Peninsula (Fig. 4). The calcareous area of the cave could have been influenced by the fluctuant marine shore that receded after the Tortonian before reaching its present state (Dercourt et al. 1985). It seems that the speciation event could have happened in the Aptiense (lower Cretaceous), suggesting that it is a primitive species, corroborated by the abundant plesiomorphies.

\section{Acknowledgements}

I am sincerely grateful to Drta Nicole Coineau, who introduced me to the study of this group and who gives me constant advice, to Prof. E. Ortiz for kindly supplying me with the material, to Dr A. G.-Valdecasas. C. Puch and to my colleagues at the Museo Nacional de Ciencias Naturales of Madrid, especially to Carolina Norena who helped with the German translations and to $M$. Ali Gago who helped me with the English translations.

\section{References}

Boutin. C. \& Coincau. N. In press. Présence du genre Iberobathynella sur le continent africain. Implications paléogéographiques.-C.r. hebd. Séanc. Acad. Sci., Paris.

Camacho, A. I. \& Coineau, N. 1987. Un nouveau représentant du genre Iberobathynella Schminke en Espagne: Iberobathynella rouchi sp.n. (Syncarida, Bathynellacea): remarques phylogénétiques et paléobiogéographiques. -Stygologia 3: 125-137.

Dercourt, J., Zonenshain, L. P., Ricou, L. E.. Karmin. V., Le Pechon, X., Knipper, A. L., Grandjacquet. C., Sborshchikov, I. M., Boulin, J., Sorokntin, O., Geyssant, S., Lepvrier, C., Bijou-Duval, P., Sibuet, J. C., Savostin, L. A., Westphal, U. \& Lauer, J. P. 1985. Présentation de 9 cartes palćogéographiques au 1/20000000 s'étendant de l'Atlantique au Permier, pour la période du Lias à l'actuel.Bull. Soc. géol. Fr. (8) 1:637-652 et suppl. Atlas

Galhano, M. H. 1967. Sur une nouvelle Parabahynella psammique du Portugal.-Publçoes Inst. Zool. Dr. Augusto Nobre 98: 9-18.

Noodt, W. \& Galhano, M. H. 1969. Studien an Crustacea subterranea (Isopoda. Syncarida. Copepoda) aus dem Norden Portugals.Publçôes Inst. Zool. Dr. Augusto Nobre 107: 9-75.

Puch, C. 1987. Atlas de las grandes cavidades españolas-Exploracions 11. $1-496$.

Schminke, H. K. 1973. Evolution, System und Verbreitungsgeschichte der Familie Parabathynellidae (Bathynellacea. Malacostraca).Mikrofauna Meeresboden 24: 1-192.

Serban, E. \& Comas i Navarro, J. 1978. Contribution à la connaissance du genre Iberobathynella Schminke: I. asturiensis sp.n. et I.espaniensis sp.n. nouvelles espèces d'Espagne (Bathynclacea, Parabathynellidae).-Trav. Inst. Spéol. Emile Racovitza 7: 13-37. 